\title{
Kuş Evleri ve Seramik Sanatçılarından Örnekler
}

\author{
Gülşen KAHRAMAN ${ }^{1}$ (i), Azize Melek ÖNDER ${ }^{2}$ \\ ${ }^{1}$ Öğr. Gör. Karamanoğlu Mehmetbey Üniversitersi, Teknik Bilimler MYO, El Sanatları Bölümü, Karaman, Türkiye, \\ gulsenkahraman_70@hotmail.com \\ ${ }^{2}$ Dr. Öğr. Üyesi, Necmettin Erbakan Üniversitesi, Güzel Sanatlar Fakültesi, Seramik Bölümü, Konya, Türkiye \\ melektolasa6@gmail.com
}

\begin{tabular}{|c|c|}
\hline Makale Bilgileri & ÖZ \\
\hline $\begin{array}{l}\text { Anahtar Kelimeler: } \\
\text { Kuş, } \\
\text { Kuş evleri, } \\
\text { Seramik Sanatı }\end{array}$ & $\begin{array}{l}\text { Anadolu'da eski bir gelenek olan kuş evlerinin geçmişi Osmanlı mimarisinde görülen örneklere } \\
\text { dayanmaktadır. Genellikle saray, cami, ev, han, medrese, kütüphane ve türbe gibi tuğla ve taş malzeme } \\
\text { üzerine iņ̧a edilen kuş evleri, mimari bir yapı kadar emek gerektiren kendine özgü yapılardır. Yapım } \\
\text { aşamasındaki zorluklar sebebi ile günümüzde yapılan mimari eserlerde kuş evlerinin üretiminin yok olmaya } \\
\text { yüz tuttuğu, var olanlarının ise korunamadığı görülmektedir. Günümüzde farklı malzemeler kullanılarak } \\
\text { yapılan kuş evlerinin birçoğu basit formlardan oluşmakta ve mimari yapıların üzerlerine inşa edilmekteyken } \\
\text { bazı kuş evleri yapıdan bağımsız olarak açı alanlarda sergilenmektedir. Bu çalışma, geçmişten günümüze } \\
\text { varlıklarını sürdüren kuş evlerini konu almaktadır. Bu kapsamda öncelikle kuş evleri hakkında literatüre } \\
\text { taraması yapıllmıştır. Seramik malzeme kullanarak kuşevleri çalışan günümüz yerli ve yabancı seramik } \\
\text { sanatçıların çalışmaları görsel açıdan incelenmiş̧tir. Bu doğrultuda kuşevi çalışan seramik sanatçıları alfabetik } \\
\text { sıra ile anlatılışır. Buna göre yurt içinden üç (Cihat Burak, Deniz Onur Erman, Mezahir Ertuğ Avşar), yurt } \\
\text { dışından beş (Douglas Fey, Jim Schatz, Joop Van Ulden, Michael Mcdowell, Stanley Cleve Bi Bitters) } \\
\text { seramik sanatçısının yaptığ1 çalışmalar görselleri ile birlikte sunulmuştur. Bununla birlikte, Karamanoğlu } \\
\text { Mehmetbey Üniversitesi kampüs alanı içine çalışılan, seramik kuş evleri yapım, uygulama süreçleri aşamalı } \\
\text { olarak anlatılmıştır. }\end{array}$ \\
\hline
\end{tabular}

\section{Bird Houses and Examples of Ceramic Artists}

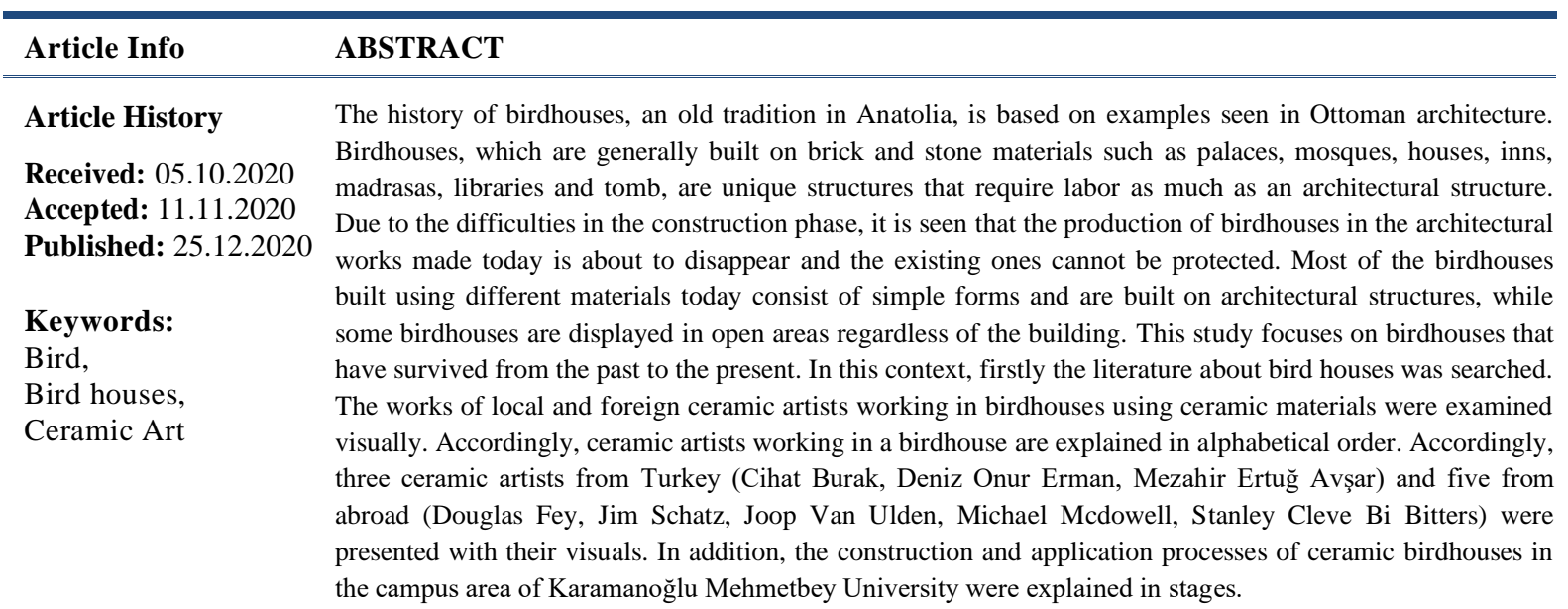

Atıf/Citation: Kahraman., G. \& Önder., A, M. (2020). Kuş Evleri ve Seramik Sanatçılarından Örnekler, Konya Sanat Dergisi, (3), 64-78.

"This article is licensed under a Creative Commons Attribution-NonCommercial 4.0 International License (CC BY-NC $4.0)^{\prime \prime}$ 


\section{GİRiș}

Yeryüzünde uzun bir geçmişe sahip olan kuşlar, hayranlık uyandırıcı uçma yetenekleriyle, insanlar için her zaman özel bir anlama sahiptir (Barışta, 2000: 27). Kuşların insanlarda taşıdığı anlam, farklı zaman ve toplumlarda bilimsel ve sanatsal çalışmalara yansımış ve daima insan yaşamı için önemli olmuştur (Erman, 2009: 1). Pek çok kültürde ve toplumda kutsal sayılan kuşlar aynı zamanda uğur getiren varlıklar olarak görülmüş ve korunmuştur. Kuş figürü her toplumda çeşitli halk hikâyeleri, masallar, mitolojik kahramanlar ve efsanelerde, sembolik anlatımlar taşımaktadır. Ayrıca kuş figürü farklı zamanlarda ve sanat dallarında bazen konu olarak, bazen plastik eleman, stilize bir şekil, soyutlama veya anlık bir görüntü biçiminde yapılarak sürekliliğini kaybetmemiştir. Sanatın her alanında önemli yer bulmuştur (Erman, 2014: 307). İnsanlığın var olmasında bu yana kuşlara olan bu ilginin sonucunda onları hayatta daha güvenli ve rahat yaşayabilmelerini sağlayacak yeni fikirler ortaya konmuştur. Bunun sonucunda insanlar kendileri için yaşama mekânlarını kurarken buna kuşları da dâhil edecek şekilde yapılar tasarlayıp geliştirerek, bahçe ve evlerinde özel bölümler ayırmışlardır (Erman, 2009: 25-26).

İslamiyette güvercinlerin, kumruların cami ve şadırvanlar etrafında, Tanrı'nın adını zikrettikleri düşüncesi (Bektaş, 2003: 51) ve Kur'an'da kuşların İslamiyet'in yayılışı sırasında Hz. Muhammed'e bazı olaylarda yardımcı olduklarının yazılmış olması sonucunda, kuşlar insanlar tarafından kutsal varlıklar olarak bilinmiş̧tir (Bektaş, 2003: 23). Bu yüzden kuşların avlanmaları günah sayılmaktadır. Türklerin kuşevleri yapmalarının altında yatan ilk sebep olarak İslam inancı gösterilebilir. Ancak bu sebep yeterli değildir. Cengiz Bektaş'ın "Kuşevleri” kitabında anlatıldığı gibi Mısır, Pakistan gibi İslam ülkelerinde güvercinlerin kutsal sayılmadığı bilinmektedir. Burada sadece İslam sanatıdan gelen faktörlerin yanı sıra (Şölenay \& Çelikoğlu, 2012: 42) Türk mitolojisinde de kuş figürünün önemli olması da etken olduğu söylenmelidir. Orta Asya'da Türklerin yaşam alanlarında çeşitli kalıntı ve buluntularda kuş figürünün oldukça yaygın olduğu görülmüştür. Özellikle bunların mezar kalıntıları olması, Türk halk inanışlarında kuşa bir anlam yüklenildiğini göstermektedir. Orta Asya Türk devlet ve boylarının dini inanışlarında etken olan "Gök Tanrı" inancı ile kuş figürüne yüklenen anlam arasında bir bağlantı kurulmuş ve gökte uçmaları sebebiyle tanrı, tanrının temsilcisi ve koruyucu ruh olarak görülmüşlerdir (Halıc1, 2014: 72).

Literatürde kuş köşkü, kuş sarayı, serçe sarayı ve güvercinlik adlarıla anılan kuş evleri, Osmanlı mimarisinde 16.-17. yüzyıldan itibaren örneklerine rastlanmaktadır. Sıva, ahşap, tuğla veya taştan inşa edilmiş olan kuş evleri çoğunlukla cami, medrese, han, kütüphane, köprü ve türbelerde görülmekle birlikte sivil mimaride de örnekleri bulunmaktadır (Barışta, 2003: 55). Kuş evleri genellikle yapıların kuzey rüzgârı almayan cephelerine ve kuşların düşmanlarının ulaşamayacağı yüksekliklere, güneşten ve yağıştan korunmaları için geniş saçakların, kornişlerin ve konsolların altına yerleştirilmiştir. Bunların en güzelleri İstanbul'da olmak üzere Anadolu ve Rumeli'de çeşitli örneklerine rastlanmaktadır (Akalın, 2020: 472). Kuş evi dönemlere göre biçimsel değişiklikler göstermekle birlikte, çoğunlukla, gerçek bir yapının minyatürü gibi tasarlanmıştır (Sözen \& Tanyeli, 1986: 143).



Görsel 1. Üsküdar Yeni Vâlide Camii’nin kuşevlerinden bir başkası (Vatan-Demir, 2019: 429). 
Serim'e göre, kuş evlerinin ilk örnekleri, Osmanlı'daki taş ustaları sayesinde ortaya çıkmıştır. Ustalar taşı yanlış yontukları zaman, taşı atmak istemeyen ustalar onu kullanır, böylece tüm taşlar birleştirilince ortada bir boşluk oluşturulur. İşte kuş evlerinin ilk örnekleri böyle oluşturulmuştur. Zamanla kuş dışkılarının cepheye değmemesi için çıkıntılı kuş evleri yapılmış, yağmurdan korunması için ufak çatılar eklenmiştir. Çoğunluğu taştan, ahşaptan, pek azı da tuğladan yapılan bu evlerin özellikle taştan yapılanları hariç ne yazık ki büyük bir kısmı yok olup gitmiştir (Serim, 2016: 5).

Osmanlı döneminde yapıların cephelerine inşa edilen kuş evleri, kuşların içinde dolaşabileceği, inip çıkabileceği odalar ve koridorlar ile minyatür bir ev tipindedir. Her yapıda farklılık gösteren kuş evlerinde konsollar üzerine kurulmuş cumba biçimli çıkıntılar, balkonlar, kemerli pencereler, çatılar, kubbeler, yemlikler, suluklar bulunur. Bu dönemde yapılan kuş evleri, İstanbul başta olmak üzere, Edirne'den Doğu Beyazıt'a kadar birçok yerdeki yapılarda rastlanılır (Albayrak, 2011: 77).

Kuş evleri örneklerine çevrimiçi olarak görsel kaynaklardan ulaşılmıştır. Birçok kuşevi formu, tasarım açısından farklı olan kuş evi örnekleri makalenin görsellerini oluşturmuştur. Bununla birlikte ulaşılan makale, tez, ansiklopedi gibi kaynakların görsel malzemeleri de kullanılmıştır. İncelenen bu örnekler doğrultusunda Karamanoğlu Mehmetbey Üniversitesi kampüs alanında sergilemeye sunulan kişisel seramik kuşevi çalışmalarının görsel bilgilerine, dış mekândaki tasarımına ayrıntıları ile yer verilmiştir. $\mathrm{Bu}$ araştırmada amaçlanan kültürel mirasın yeni nesle aktarılması ve öneminin kavratılması kuşevleri yoluyla verilmek istenmiştir.

\section{Seramik Sanatında Kuşevi Uygulamaları}

Seramik en basit tanımıyla hammaddesi kil olan organik olmayan malzemelerin çeşitli tekniklerle belirli bir üretim sürecinde şekillendirilip pişirilerek sert, dayanıklı, kullanım alanına bağlı olarak estetik ve hijyenik özellikler kazanması ile oluşturulan malzeme ve bu malzemenin kullanımı ile ortaya çıkan sanat dalıdır (Toydemir, 1991: 2). Seramik, yüksek derece pişiriminde bünyesinde oluşan değişikliklerle geçirimsiz, sert, kimyasal ve fiziksel aşınmalara karşı dirençli yapısına, gaz giriş ve çıkışına izin vermeyen, dış mekânlarda da rahatlıkla kullanılabilen, estetik yönü bulunan çevreye uyum sağlayan bir malzemedir (Zümrüt, 2013: 469). Seramik malzemenin plastik özelliğe sahip olması, doku, renk, doğa ile uyumlu olması kuş evlerinde seramik malzemenin kullanılmasına olanak sağlanmıştır. Malzemenin sağladığı imkânlardan faydalanılarak mimari yapıların yüzeylerinde seramik kuş evlerinin yapımı mümkündür. Günümüzde seramik alanında yapılan kuş evleri, tasarımcı ve sanatçılar tarafından yeniden yorumlanmakta ve bazı mimari yapılarda sergilenmektedir (Biçici, 2010: 16-17).

Seramik sanatında kuş evi çalışmaları yapan pek çok seramik sanatçısı bulunmaktadır. Cumhuriyet döneminin ilk Türk kadın seramik sanatçısı olan Füreyya Koral ile başlayan kuş evi yapımı Sadi Diren, İlgi Adalan, Güngör Güner, Zehra Çobanlı, Emel Şölenay, S. Sibel Sevim, Ayşegül Türedi Özen, Cihan Burak, Mezahir Ertuğ Avşar, Deniz Onur Erman, Gülşen Kahraman gibi seramik sanatçıları ile devam etmiştir. Bunların arasında eserlerine ulaşılan seramik sanatçıları aşağıda verilmiştir.

\subsection{Kuş Evi Çalışan Ulusal Seramik Sanatçıları}

\subsubsection{Cihat Burak}

Cihan Burak, seramik kuş evi çalışan Türk sanatçıların arasında ilk akla gelen isimlerdendir. Sanatçı, kuş evlerini mimari yapılar olan köşk ve türbeler için özel tasarlamıştır (Şölenay \& Çelikoğlu, 2012: 49). Cihat Burak, çatı görünümlü, kırmızı kilden yapılmış “Beyler Beyi Sarayı Deniz Köşkü Kuş Evi'nde" Türk mimari yapılar içinde özgün bir yeri olan kuşevlerini ele almıştır. Gerçeğinin özgün bir 
yorumu olan çalışmalar kültürel mirasa katkı sağlayan görsel belgelerdir (Aktuğ, 2010: 26) (Görsel 23-4-5).



Görsel 2. Cihat Burak, Beylerbeyi Sarayı

Deniz Köşkü Kuşevi.

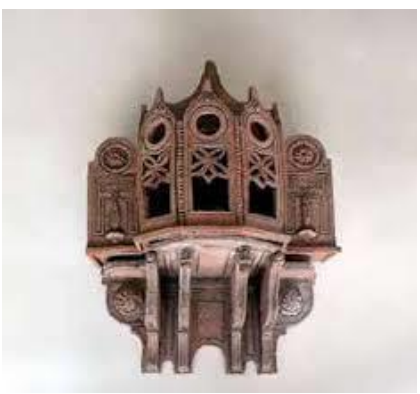

Görsel 4. Cihat Burak, Beylerbeyi Sarayl Deniz Köşkü Kuşevi.



Görsel 3. Cihat Burak, Beylerbeyi Sarayı Deniz Köşkü Kuşevi.

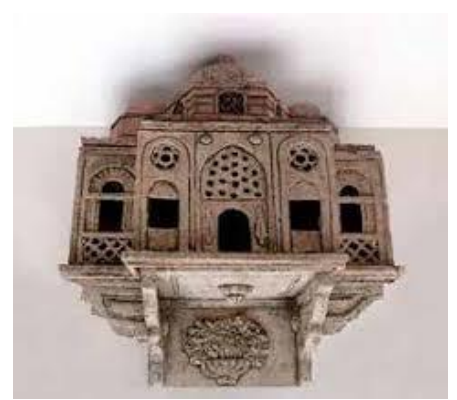

Görsel 5. Cihat Burak, Laleli Mustafa III Türbesi Kuşevi.

\subsubsection{Deniz Onur Erman}

Sanatçı porselen ve yüksek pişirim teknolojileri, figüratif seramik, papeclay, seramik ve hikayeci, mizahi anlatımlar konuları ile ilgili çalışmaları bulunmaktadır (Erman, 2020). Son dönem çalışmaları içinde kuş ve kadın formları, baykuş figürleri, kil ile çalıştı̆̆ı hamile kadın figürleri, renkli porselen, farklı malzemeleri bir arada kullandığı yüzey çalışmaları ve saatleri bulunmaktadır (Erman, 2017) (Görsel 6-7).

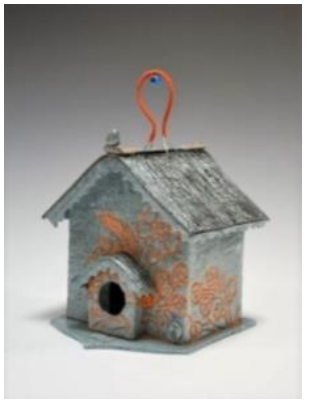

Görsel 6. Deniz Onur Erman, Kuşevi-mavi turuncu, serbest elde şekillendirme, sirl porselen, $1260{ }^{\circ} \mathrm{C}, \mathrm{h}=40 \mathrm{~cm}, 2013$.

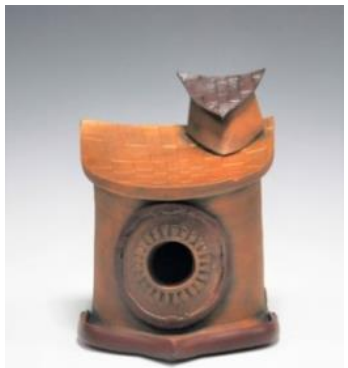

Görsel 7. Deniz Onur Erman, Kuşevi, serbest elle şekillendirme, kırmızı kil, $1000 \mathrm{oC}, \mathrm{h}: 30 \mathrm{~cm}, 2013$. 


\subsubsection{Mezahir Ertuğ Avşar}

Mezahir Ertuğ Avşar, seramik sanatında Türk halkının tarihi ve kültürü konusunda önemli eserler vermiştir. Eski Türk damgaları, Orhun-Yenisey yazıtları, Türk mitolojisi, Erken Dönem Türk sanatı simge ve motifleri sanatçı tarafından çağdaş yorum ve anlayış içinde ele alınmaktadır. Sanatçı, Türk sanatı için önemli bir yeri olan kuşlar için Selçuk Üniversitesi Sanat ve Tasarım Fakültesi ön bahçesine yüksek lisans öğrencileri ile birlikte çalıştığ " "kuş evleri” ile bilinmektedir (Görsel 8).

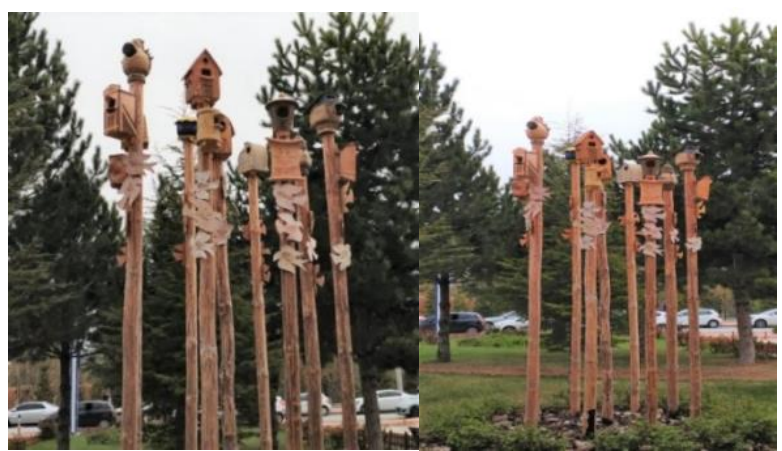

Görsel 8. Prof. Mezahir Avşar ve Yüksek Lisans Öğrencileri ile Birlikte Yaptığ "Seramik Kuş Evleri" Çalışması, Selçuk Üniversitesi, Sanat ve Tasarım Fakültesi Ön Bahçe Alanı (kişisel arşiv)

\subsection{Kuş Evi Çalışan Uluslararası Seramik Sanatçıları}

\subsubsection{Douglas Fey}

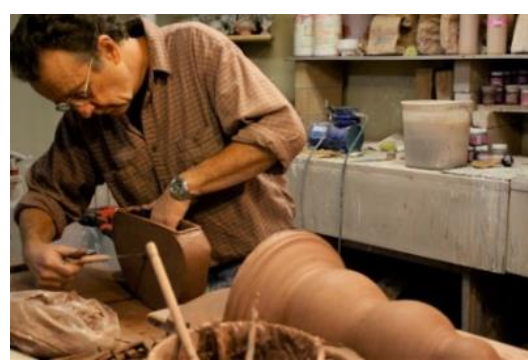

Görsel 9. Douglas Fey, Atölye Ortamında Çalışması



Görsel 10. Douglas Fey Kedi Biçimli Kuşevi.

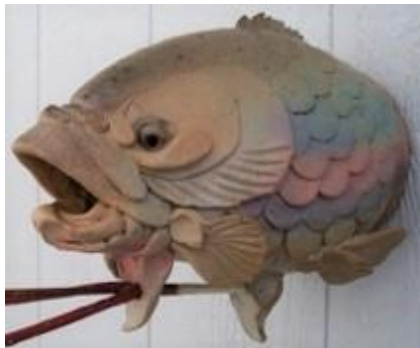

Görsel 11. Douglas Fey, Balık Biçimli Kuşevi.

Amerikalı sanatçı Douglas Fey, seramikten yaptı̆̆ı fantastik yaratıklar ve hayvanların kafalarından kuş evleri tasarlamaktadır. Tasarımlarına "kuş gargaracısı (bird gargler)" ismini vermiştir. Çalışmaları arasında kedi, köpek, balık, sürüngenler, dinozorlar, fantastik yaratıklar ve "goon" ismini verdiği ay, güneş ve rüzgâr gibi doğa olaylarını temsil eden kafalar bulunmaktadır. Dekoratif amaçlı çalışmalarda sırlı ve çok renkli, fonksiyonel çalışmalarda ise sırsız ve toprak renklerinde seramik kuş evleri tasarlamıştır (Şölenay \& Çelikoğlu, 2012: 47) (Görsel 9-10-11).

\subsubsection{Jim Schatz}

Amerikalı sanatçı minimal formlarda yaptığı seramik tasarımlarıyla oldukça popüler olmuştur. Özellikle gökkuşağı renginde, parlak yumurta şeklinde seramik kuş evi tasarımları dikkat çekmiştir. Değişik renklerde sırlanmış olan kuş evleri, hava koşullarına dayanıklı, renkli ve estetik çalışmadır (Şölenay \& Çelikoğlu, 2012: 47) (Görsel 12). 


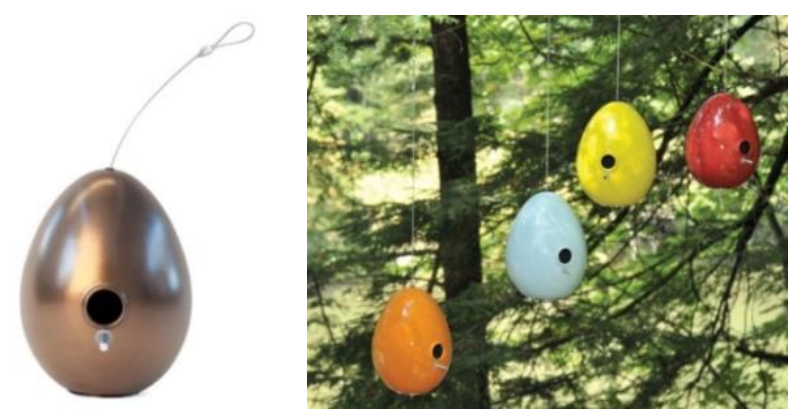

Görsel 12. Jim Schatz’’n Yumurta Görünümlü Kuşevi Çalışmaları

\subsubsection{Joop Van Ulden}

1998 yılından beri Brummen'de seramikle uğraşan sanatçı kuş evleri ve bahçe seramiği ile alakalı çalışmalar yapmıştır. Yaptığı seramik eserleri yaklaşık $1275{ }^{\circ} \mathrm{C}$ sıcaklıkta pişirim yapmaktadır (Görsel 13).

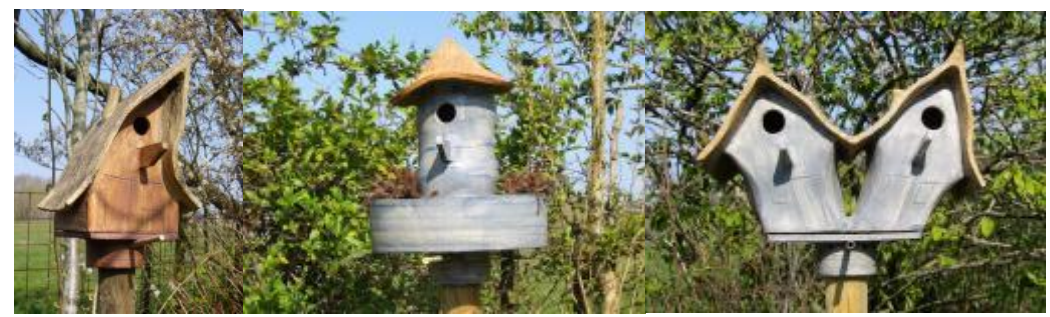

Görsel 13. Joop van Ulden'in Seramik Kuşevi Çalışmaları

\subsubsection{Michael McDowell}

Denver, Colorado'da yaşayan McDowell, sade tasarımlı çalışmalarıyla dikkat çekmektedir. İç kısmında beyaz renkte sır, dış kısmında ise toplanmalı beyaz sır kullandığı mantar şeklinde, beyaz ve küre şekilli kuş evi tasarımları oldukça popüler olmuştur (Şölenay \& Çelikoğlu, 2012: 48) (Görsel 14).

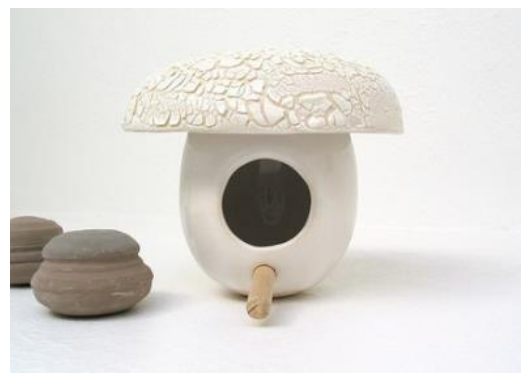

Görsel 14. Michael McDowell'in Seramik Kuş Evi Çalışması

Sanatçının çalıştığı seramik kuş evileri özgün bir yorumla tasarlanmıştır. Dış mekâna yerleştirilen kuş evleri, kişisel bir üslupla işlevsellik, dekorlama ve tasarım açısından özgün seramik çalışmaları olarak oluşturulmuştur.

\subsubsection{Stanley Cleve Bitters}

California'da yaşamını sürdüren ve mimari seramik alanında çalışmaları bulunan sanatçı, büyük ölçekli çalışmalarının yanı sıra seramik duvar resimleri, heykeller, çeşmeler ve bahçe yolları, renkli görünümlü taşlara benzeyen seramik kuş evleri bulunmaktadır (Görsel 15). 


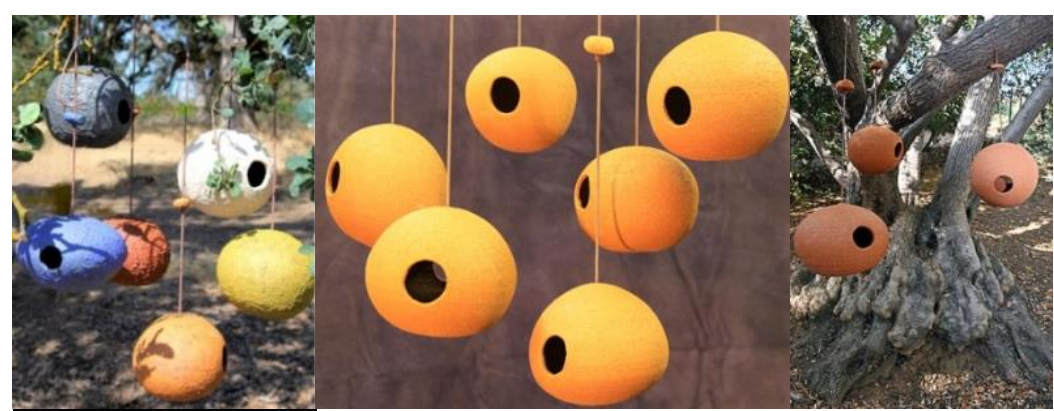

Görsel 15. Stanley Cleve Bitters 'in Seramik Kuşevi Çalışmaları

\section{Seramik Kuş evi Üzerine Kişisel Uygulamalar}

Sanatsal tasarımın ana temasını seramik kuş evleri oluşturmuştur. Araştırmanın bu bölümünde önceki inceleme ve araştırmalar ışığında özgün seramik kuş evleri ortaya konuulmaya çalışılmıştır. Çalışma Karamanoğlu Mehmetbey Üniversitesi dış mekân bahçe düzenlemesi için tasarlanan 20 adet farklı ebatlarda seramik kuş evi uygulamasından oluşmaktadır. Bu tema çerçevesinde her bir kuş evi çalışmasının tasarımı ele alınan konu içeriğindeki detaylardan esinlenerek kurgulanmıştır. Çalışmalar dört ayrı yerde sergilenmiştir. Çam sırıklar üzerine yerleştirilen toplam 16 adet seramik kuş evi çalışması, 51 adet seramik kuş, 17 adet seramik yaprak çalışması üç farklı alana kombine edilerek yerleştirilmiştir. Dört adet çalışma ise aynı mekânda ağaç dallarına asılarak monte edilmiştir. Dekorlamada doğaya uygun renkler kullanılarak görsel bütünlük oluşturulmaya çalışılmıştır.

Çalışmalara ilk olarak eskiz yapımı ile başlanmış ve konu ile ilgili fotoğraf, çeşitli belge ve dökümanlardan faydalanılmıştır. Uygulama aşamasında şamotlu çamur ve plastik akçini çamuru tercih edilmiştir. Dekorlamada astar ve sır kullanılmıştır. Ön hazırlık aşamasında dikkat edilen ayrıntılar ise; tasarımda, kuşların hava şartlarından ve diğer olumsuz etkenlerden korunabilmeleri amaçlanmaktadır. Farklı kuş türlerinin barınabilmesi için giriş açıklığ 1 farklı boyutlarda ayarlanmıştır. Kuşların yuva içine girmeden konabilmeleri için yuva ağzının bulunduğu kısma tahta çubuklar yerleştirilmiştir. 16 adet çalışmanın alt kısımlarına sırık üzerine oturtabilmek için bant şeklinde kalınlıklar verilmiştir. Kuşevleri ve yapraklar şamotlu çamurla çalışılmış, seramik kuşlarda akçini çamuru kullanılmıştır. Serbest elde ve kalıpta şekillendirme yapılmıştır.



Görsel 16. Atölye Çalışması ve Kalıpta Şekillendirme Örneği (kişisel arşiv).

İlk pişirimi $950{ }^{\circ} \mathrm{C}^{\prime}$ yapılan seramik ürünlerin dekorlama aşamasında bir kısım ürünler üzerine oksit sır karışımı sürülerek sür-sil uygulaması, astarlı ürünler üzerinde ise şeffaf sır uygulaması yapılmıştır. 


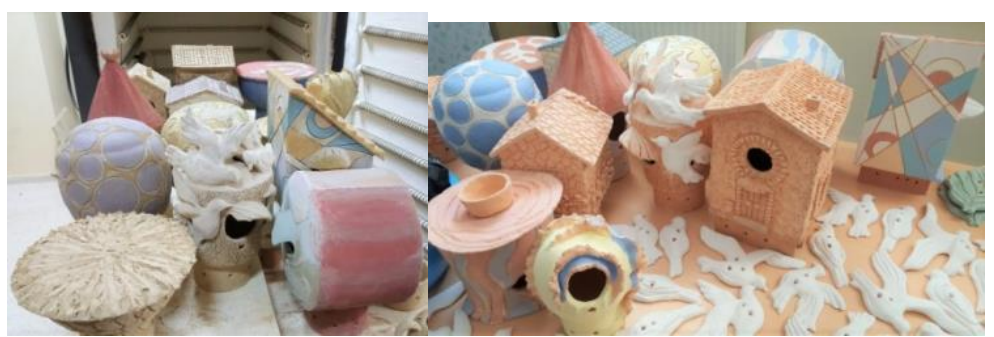

Görsel 17. İlk Pişirim için firına yerleşmiş $\left(950^{\circ} \mathrm{C}\right.$ pişirim) ve pişirim sonrası seramik ürünler (kişisel arşiv)

"Antik" isimli kuş evi çalışması bantlı, uzun dikdörtgen formlu ve tek katlı bir ev görünümdedir. Dekorlamada, lacivert, beyaz renkte oksit ve şeffaf sır uygulaması yapılmıştır (Görsel 18). "Kütük" isimli kuş evi çalışması bantlı, kütük formlu bir görünümdedir. Dekorlamada, siyah, yeşil renkte astar ve şeffaf sır kullanılmıştır (Görsel 19).

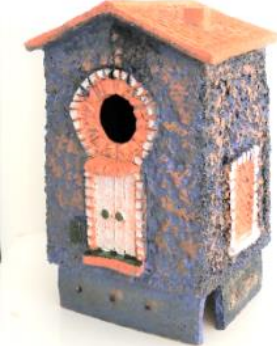

Görsel 18 “Antik”, $34 \times 20 \times 17 \mathrm{~cm}$, $1040^{\circ} \mathrm{C}$ (kişisel arşiv)

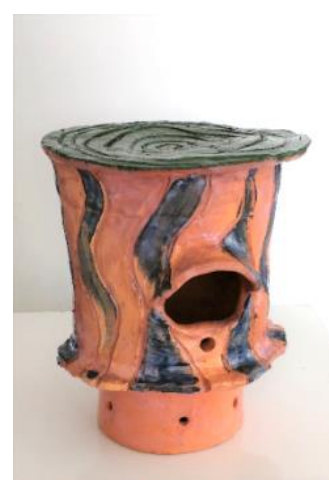

Görsel 19. "Kütük”, $25 \times 21 \mathrm{~cm}$, $1040{ }^{\circ} \mathrm{C}$ (kişisel arşiv)

"Şapkadan" isimli çalışma bantlı ve yuvarlak formludur. Dekorlamada, yeşil renk ve şeffaf sır kullanılmıştır (Görsel 20). "Kuşlar" isimli çalışma bantlı, silindirik formludur. Çatı ve gövdesinde kabartma şeklinde uçan kuşlar bulunmaktadır. Dekorlamada, sarı, beyaz renk, oksit ve şeffaf sır kullanılmıştır (Görsel 21).



Görsel 20. "Şapkadan”, 20x19 cm, $1040^{\circ} \mathrm{C}$ (kişisel arşiv)

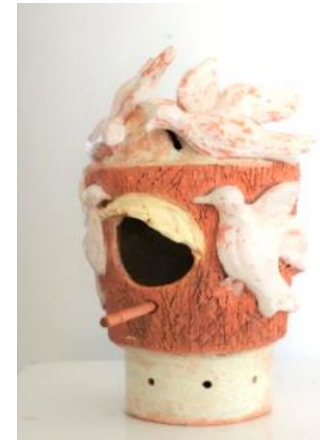

Görsel 21. "Kuşlar”, $36 \times 20 \mathrm{~cm}$, $1040{ }^{\circ} \mathrm{C}$ (kişisel arşiv)

"Yaşam" isimli çalışma bantlı, kare formludur. Üzerinde kabartma olarak yapılmış kuşlar, çiçekler, merdiveni biçimleri ve mozaik görüntüsü eklenmiştir. Dekorlamada, beyaz astar, sarı, siyah renk ve astar kullanılmıştır (Görsel 22). "Mavi Ev" isimli çalışma bantlı ve yarım daire formludur. Dekorlamada, lacivert, beyaz, kahve renkte astar ve şeffaf sır kullanılmıştır (Görsel 23). 


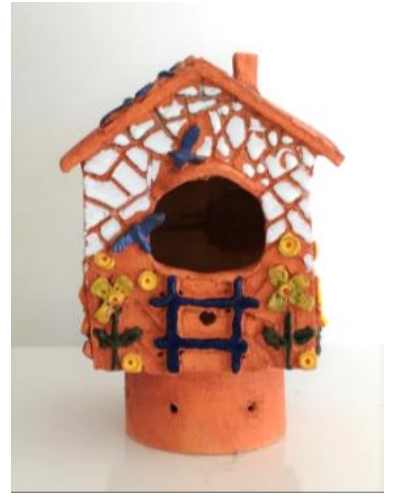

Görsel 22. "Yaşam”, $27 \times 15 \times 15 \mathrm{~cm}$, $1040^{\circ} \mathrm{C}$ (kişisel arşiv)

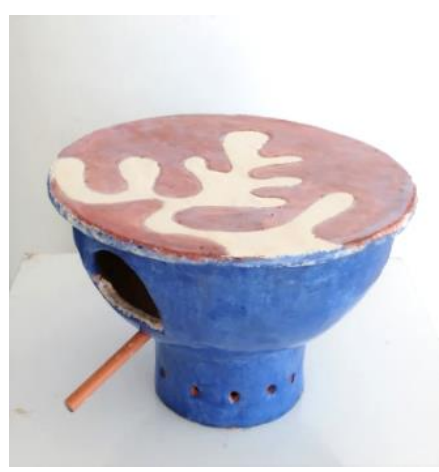

Görsel 23. "Mavi Ev", 27x18 cm, $1040^{\circ} \mathrm{C}$ (kişisel arşiv)

"Krater" isimli çalışma bantlı ve dairesel formludur. Dekorlamada, lacivert, beyaz renkte astar ve şeffaf sır kullanılmıştır (Görsel 24). "Gizem" isimli çalışma bantlı ve dairesel formludur. Dekorlamada, sarı, beyaz renkte astar ve şeffaf sır kullanılmıştır (Görsel 25).

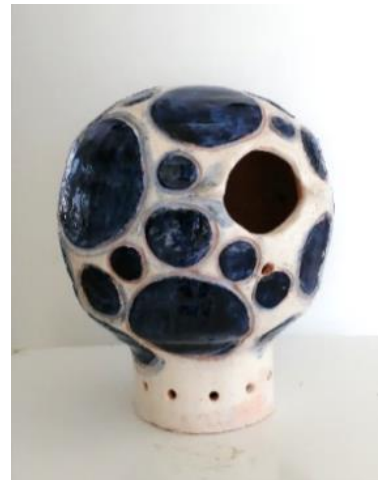

Görsel 24. "Krater”, $29 \times 23 \mathrm{~cm}$, $1040^{\circ} \mathrm{C}$ (kişisel arşiv)



Görsel 25. “Gizem”, 27x24 cm, $1040^{\circ} \mathrm{C}$ (kişisel arşiv)

"Mozaik" isimli çalışma bantlı ve yarım daire formludur. Dekorlamada, lacivert, beyaz renk, oksit ve şeffaf sır kullanılmıştır (Görsel 26). "Geometrik" isimli çalışma bantlı ve yamuk formludur. Dekorlamada, sarı, turuncu, yeşil, lacivert, beyaz, kahverengi, turkuaz, beyaz renkte astar, oksit ve şeffaf sır kullanılmıştır (Görsel 33).

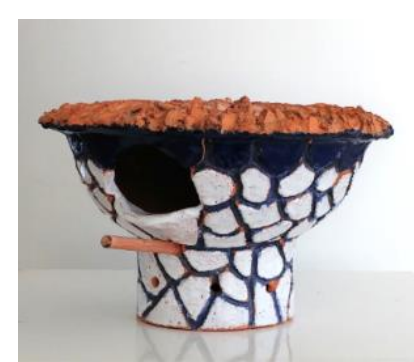

Görsel 26. "Mozaik", 16x27 cm, $1040{ }^{\circ} \mathrm{C}$ (kişisel arşiv)

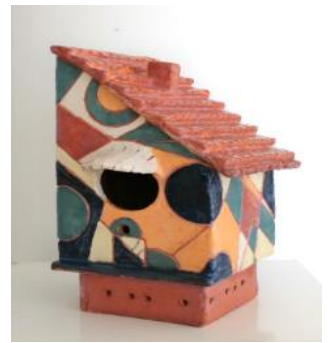

Görsel 27. "Geometrik", 19x6x17 cm, $1040{ }^{\circ} \mathrm{C}$ (kişisel arşiv)

"Taş Bina" isimli çalışma bantlı ve kare formludur. Dekorlamada, lacivert, beyaz renkte astar ve şeffaf sır kullanılmıştır (Görsel 28). "Hayal" isimli çalışma bantlı ve dairesel iki plaka arasına geniş bir bant çevrelenmiş bombeli formludur. Dekorlamada, beyaz, camgöbeği renkte astar, oksit ve şeffaf sır kullanılmıştır (Görsel 29). 


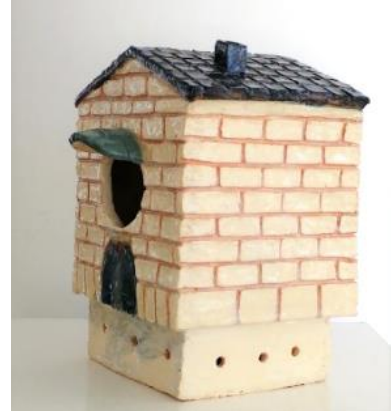

Görsel 28. "Taş Bina”, 27x20x16 cm, $1040^{\circ} \mathrm{C}$ (kişisel arşiv)

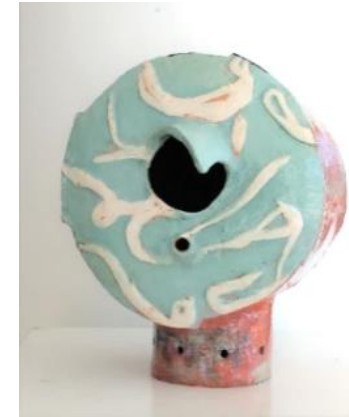

Görsel 29. "Hayal”, 32x26x17 cm, $1040^{\circ} \mathrm{C}$ (kişisel arşiv)

"Dokusal" isimli çalışma bantlı ve oval formludur. Dekorlamada, sarı ve lacivert renkte astar ve şeffaf sır kullanılmıştır (Görsel 30). "Kümbet" isimli çalışma bantlı ve Selçuklu Kümbettlerini andıran bir formda oluşturulmuştur. Dekorlamada, beyaz, camgöbeği, kahve renkte astar ve şeffaf sir kullanılmıştır (Görsel 31).



Görsel 30. "Dokusal”, $22 \times 17 \mathrm{~cm}$, $1040^{\circ} \mathrm{C}$ (kişisel arşiv)

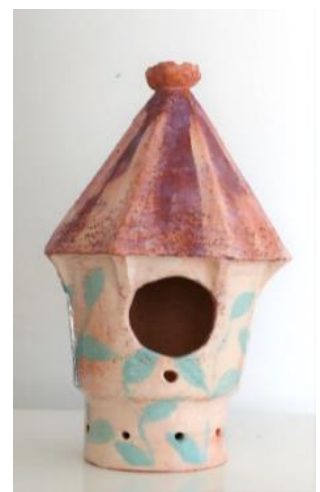

Görsel 31. "Kümbet”, 39x18 cm, $1040^{\circ} \mathrm{C}$ (kişisel arşiv)

"Virane" isimli çalışma bantlı ve diktörgen formludur. Dekorlamada, oksit ve renkli sır kullanılmıştır (Görsel 32). "Gaudi'den Esintiler" isimli çalışma bantlı ve yamuk formludur. Dekorlamada, renkli sır kullanılmıştır (Görsel 33).



Görsel 32. "Virane”, 46x16x14 cm, $1040^{\circ} \mathrm{C}$ (kişisel arşiv)

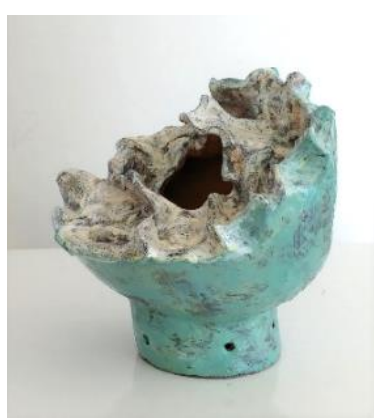

Görsel 33. "Gaudi'den Esintiler”, 19x19x10 cm, $1040^{\circ} \mathrm{C}$ (kişisel arşiv)

Seramik kuşevi çalışmalarının mekânda uygulama aşaması ise; altı metrelik çam sırıklar yarım metre derinliğindeki çukurların içlerine beton atılarak oturtulmuştur. Yaklaşık bir hafta betonun kuruması beklenmiştir. Beton kuruduktan sonra kuş evlerinde bulunan bantlar sırıklara oturtularak 
vida ile sabitlenmesi yapılmıştır. Sergilenme alanları Karamanoğlu Mehmetbey Üniversitesi Rektörlük binası bahçe alanının karşılıklı iki farklı yönü ve yine kampüs alanı içinde bulunan Roma evi önüne yerleştirilmiştir (Görsel 34-35-36).



Görsel 34. Tasarım I, 7 Adet Kuş Evi Çalışmasının Uygulanma ve Genel Görünümü, Karamanoğlu Mehmetbey Üniversitesi, Rektörlük Binası, Dış Mekân Bahçe Alanı, Sol Yön Uygulama Alanı, 2019, Karaman (kişisel fotoğraf arşiv)

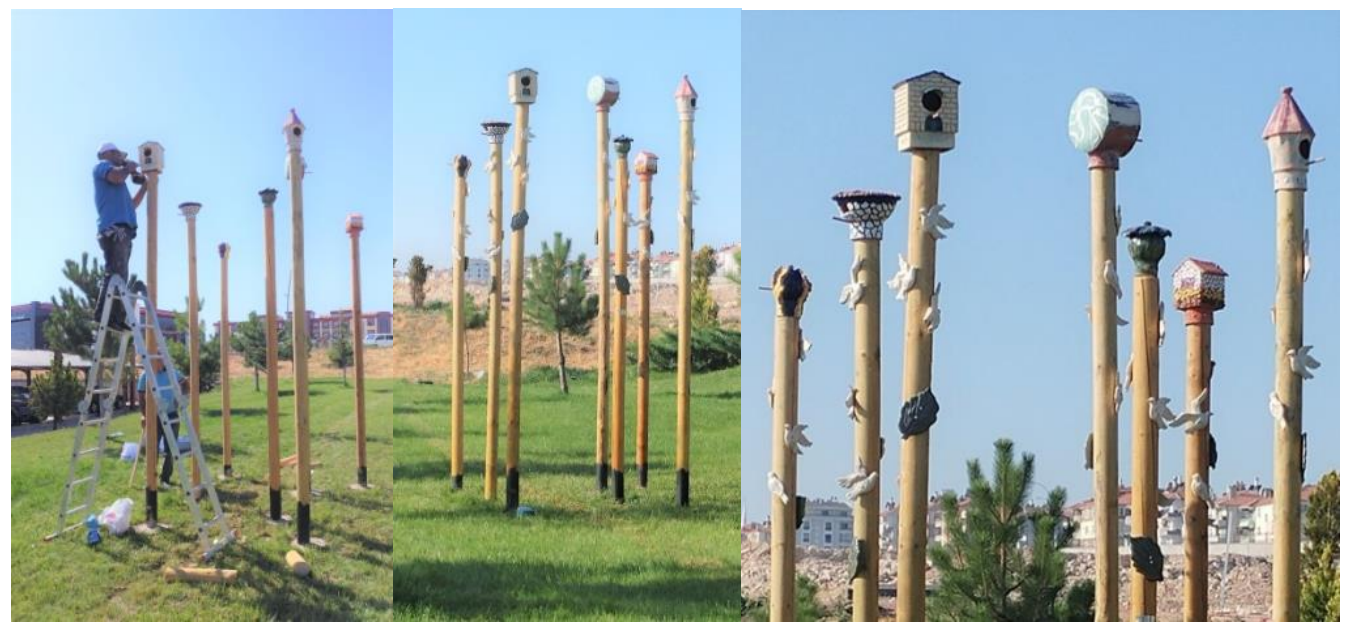

Görsel 35. 7 Adet Kuş Evi Çalışmasının Uygulanma ve Genel Görünümü, 2019, Karamanoğlu Mehmetbey Üniversitesi, Rektörlük Binası, Dış Mekân Bahçe Alanı, Să̆ Yön Uygulama Alanı, Karaman (kişisel fotoğraf arşiv).

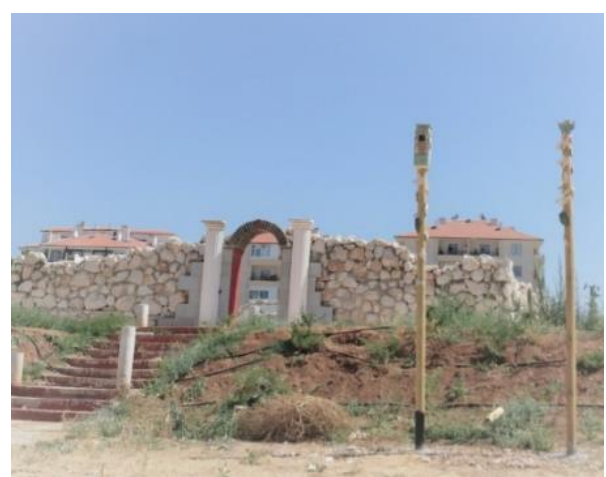

Görsel 36. Adet Kuş Evi Çalışmasının Genel Görünümü, Roma Evi Alanı, 2019, Karamanoğlu Mehmetbey Üniversitesi , Karaman (kişisel fotoğraf arşiv) 
İkinci tasarım "Yuva I, II, III, IV" isimli kuş evi serisi dört adet geometrik formlu çalışmadan oluşmaktadır. Şamotlu çamur kullanılarak plaka yöntemiyle elle şekillendirme yöntemi kullanılarak yapılmış olan çalışmlar, turkuaz, pembe, yeşil, sarı renkte astar ile dekorlanmıştır. Fırınlama aşamasından sonra şeffaf sır kullanılarak tekrar firınlanmıştır (Görsel 37-38-39-40). Biten çalışmalar ağaç dallarına asılmıştır (Görsel 41).

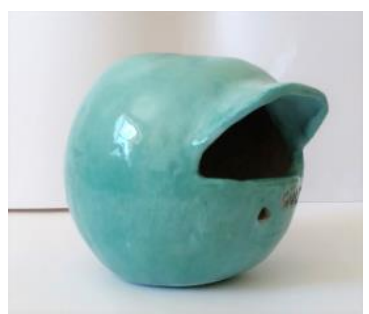

Görsel 37. Gülşen Kahraman'ın Yuva I Konulu Kuş Evi Çalışması $14 \times 15 \mathrm{~cm}, 1050,{ }^{\circ} \mathrm{C}, 2019$,

Karamanoğlu Mehmetbey Üniversitesi,

Teknik Bilimler Meslek Yüksekokulu Bahçe Alanı, Karaman (kişisel arşiv)

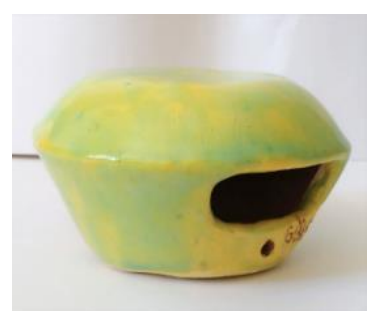

Görsel 39. Gülşen Kahraman'in Yuva III Konulu Kuş Evi Çalışması $9 \times 16 \mathrm{~cm}, 1050,{ }^{\circ} \mathrm{C}, 2019$,

Karamanoğlu Mehmetbey Üniversitesi,

Teknik Bilimler Meslek Yüksekokulu Bahçe Alanı, Karaman (kişisel arşiv)

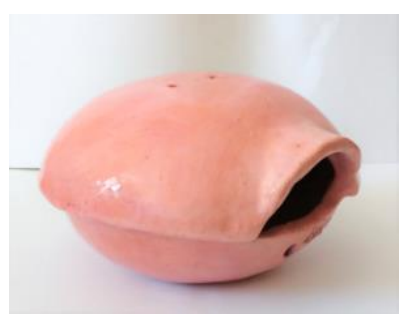

Görsel 38. Gülşen Kahraman' ’n Yuva II Konulu Konulu Kuş Evi Çalışması $12 \times 18 \mathrm{~cm}, 1050^{\circ} \mathrm{C}$, 2019, Karamanoğlu Mehmetbey Üniversitesi, Teknik Bilimler Meslek Yüksekokulu Bahçe Alanı, Karaman (kişisel arşiv)

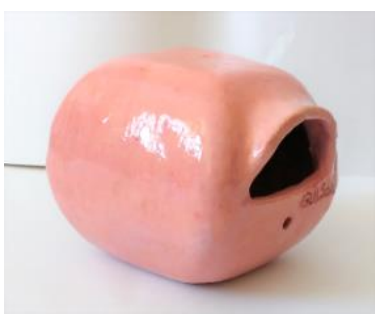

Görsel 40. Gülşen Kahraman'in Yuva IV Konulu Konulu Kuş Evi Çalışması $13 \times 15 \mathrm{~cm}, 1050{ }^{\circ} \mathrm{C}$, 2019, Karamanoğlu Mehmetbey Üniversitesi, Teknik Bilimler Meslek Yüksekokulu Bahçe Alanı, Karaman (kişisel arşiv)
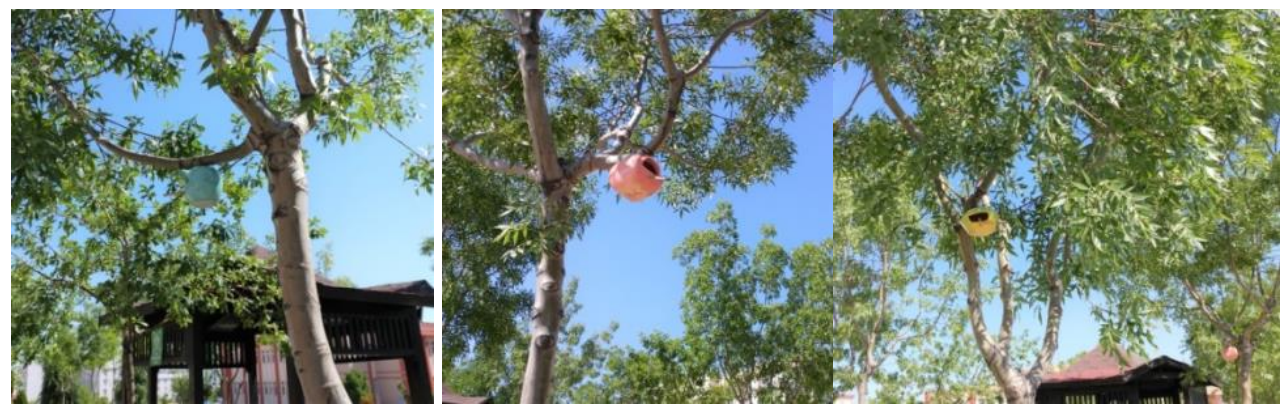

Görsel 41. "Yuva I, II, III, IV”, Seramik Kuş Evi Çalışmasının Genel Görünümleri, Karamanoğlu Mehmetbey Üniversitesi, Teknik Bilimler Meslek Yüksekokulu Bahçe Alanı, Karaman (kişisel arşiv)

Sanatsal çalışmaların sergilenmesi açık alan olması sebebiyle ziyaretçinin anlık da olsa ilgisini çekmektedir. Bir kısmı ahşap konstrüksiyon ve seramik malzemeden oluşan çalışmalar biçimsel ve doğal yapısıyla uyumlu duruşunun yanı sıra insan hayatına gönderme yapılmış hissi uyandırmaktadır. $\mathrm{Bu}$ tür farklı açık alan uygulamaları mekâna görsel zenginlik ve kavramsal bir anlatı katması hedeflenmiştir. 


\section{SONUÇ}

Kuş evleri, Türklerin hayvanlara özellikle de kuşlara verdikleri değer ve önemi göstermektedir. Kuşlara verilen bu önemin ilk göstergeleri Osmanlı döneminde mimari eserler üzerine inşa edilen kuş evleri ile belgelenmiştir. Bu dönemde inşa edilen kuş evleri günümüz seramik sanatçıları tarafından beğenilmiş ve yeniden biçimlendirilmiştir. Bu tip eserlerin günümüz örneklerini seramik sanatçısı Cihan Burak ele almıştır.

Seramik malzemenin sanatta bir ifade aracı olarak kullanılması, bu alanda yapılan çalışmaların çeşitlenmesine olanak sağlamıştır. Kuş evleri bu çeşitliliğin iyi bir göstergesi olarak günümüz seramik sanatında hala varlığını sürdürmektedir. Günümüzde seramik malzeme ile farklı kuş evleri tasarlandığı görülmektedir. Bunlar, nadir de olsa Osmanlı döneminde olduğu gibi mimari eserlerin dış duvarlarına ve çoğunlukla mimari eserlerden bağımsız olarak ağaç, kaide gibi farklı eklentiler ile birlikte tasarlanmaktadır. Bunların haricinde bugün kuş evleri ile ilgili tasarımlar sembolik olarak da yapılmaktadır. Kullanım amacı olmadan sadece görsel olarak kuş evlerini sembolize eden tasarımların varlı̆g 1 da az değildir.

Günümüz Türk seramik sanatçılarının kuş evleri konusunda yaptığı çalışmalar bugün yeterli olmamakla birlikte varlığını sürdürmektedir. Bu kapsamda makalede bahsedilen Prof. Mezahir Ertuğ Avşar'ın yönetiminde Selçuk Üniversitesi Kampüs alanı içerisinde yüksek lisans öğrencileri ile birlikte yapmış olduğu çalışma örnek teşkil etmektedir. Bu örneğin bir benzeri Karamanoğlu Mehmetbey Üniverstitesi kampüs alanı içerisine de yapılmıştır. Karamanoğlu Mehmetbey Üniversitesinde Öğretim görevlisi olan ve Mezahir Ertuğ Avşar'dan Yüksek Lisans dersi alan Gülşen Kahraman, çalıştı̆̆ üniversitenin açık alanlarına 20 parça seramik kuş evi tasarlamış, bunlardan 16 tanesi altı metrelik çam sırıklar üzerine monte edilerek kalıcı hale getirmiştir. Kalan 4 tane çalışma ise ağaç dallarına yerleştirilmiştir. Bu tasarımların her aşaması yukarıda detayları verilerek anlatılmıştır. Ana malzeme seramik çamuru olup, şamot ve plastik döküm kili kullanılmıştır. Şekillendirme yöntemi olarak serbest elle şekillendirme ve kalıpta şekillendirme, dekorlanmasında ise astar, sıraltı boya karışımı uygulanmıştır. Dış mekânlarda uygulaması yapılan bu çalışmaların amacı, izleyenlere görsel zenginlik ve estetik değer kazandırmak ve ileride kuş evleri ile ilgili çalışmalara kaynak oluşturmaktır.

Sonuç olarak, günümüz seramik sanatçılarının kuş evleri ile ilgili yaptıkları çalışmaları bir araya getirerek konu hakkında yapılan çalışmalara ek olarak yeni bir kaynak oluşturmaktır. Aynı zamanda seramik kuş evi yapım süreci, süslemesi, dış mekana monte aşaması gibi bir çok merak edilen konular görseller ile anlatılarak literature katkı sağlanmıştır.

\section{KAYNAKÇA}

Akalın., Ş. (2002). Kuşevi. İslam Ansiklopedisi. 26.cilt, s. 472-473.

Aktuğ., A, C. (2010). Seramik eserlerde evin anlamı. Sanat ve Tasarım Dergisi. 1(6), 23-33.

Albayrak., G, A. (2011). Osmanlı'nın minyatür sarayları. Hukuk Gündemi. Mart. 77-79.

Barışta., Ö. (2000). Osmanlı Imparatorluğu dönemi Istanbul'undan kuşevleri. Kültür Bakanlığı Yayınları. Birinci Bask1.

Bektaş., C. (2003). Kuşevleri. Literatür Yayınları.

Biçici., Ş. (2010). Seramik ürünlerle ve ürünlerde kent imajı. (Yayımlanmamış Yüksek Lisans Tezi) Çanakkale Onsekiz Mart Üniversitesi Sosyal Bilimler Enstitüsü.

Bitters., C, S. (2020). Bio, http://www.stanbitters.com/bio/ (Erişim Tarihi: 27.07.2020).

Erman., O, D. (2009). Seramik sanatında kuş figürü üzerine kişisel uygulamalar. (Yayımlanmamış Sanatta Yeterlilik Tezi) Hacettepe Üniversitesi Sosyal Bilimler Enstitüsü. 
Erman., O, D. (2017). Siyah kuğu-beyaz kuğu, https://www.galerisoyut.com.tr/deniz-onur-erman2017/\#sanatci-tab (Erişim Tarihi: 20.07.2020).

Erman., O, D. (2020). https://websitem.gazi.edu.tr/site/deniz.erman/thesis (Erişim Tarihi: 20.07.2020).

Halıcı., G, Y. (2014). Gök Tanrı'nın temsilcileri: koruyucu kuşlar. folklor/edebiyat. 20(77), 2014/1, https://dergipark.org.tr/en/download/article-file/255630

Kaptan., Ö. (2016). Kent kültüründe bir değer olarak seramik. 10. Uluslararası Eskişehir Pişmiş Toprak Sempozyumu Bildiriler Kitabı. Eylül-Ekim. Tepebaş1 Belediyesi, 96-102.

Kenan., L. (2019). Sanatın işlevselliği bağlamında kamusal alan örneklemeleri. International Journal of Interdisciplinary and Intercultural Art Dergisi. 4(8), 81-98.

Serim., Ö, R. (2016). Anadolu medeniyetinde kuş evleri ve güvercinler.

Sözen., M. \& Tanyeli., U. (1986). Sanat kavram ve terimleri sözlüğ̈̈. Remzi Kitabevi. Evrim Matbaacilik.

Şölenay., E. \& Çelikoğlu., Ö. (2012). Bir malzeme olarak seramiğin kuşevlerinde kullanılması. Sanat ve Tasartm Dergisi 2 (2), 41-51.

Toydemir., N. (1991). Seramik yapı malzemesi. İTÜ Mimarlık Fakültesi.

Özdağ., E, D. (2017). Çağdaş Türk sanatında gerçek dışı kuş figürleri. JRES (Journal of Research in Educatıon and Socıety) Eğitim ve Toplum Araştırmaları Dergisi. 4 (1), 17-32.

Zümrüt., Y. (2013). Çevresel sanat ve çevreci yaklaşımla yapılan seramik uygulamalar. 7. Uluslararası Eskişehir Pişmiş Toprak Sempozyumu. 465-479.

\section{GÖRSEL KAYNAKÇASI}

Görsel 1. Vatan, A-Demir, Ö. (2019). “İstanbul’daki Kuş Sarayları: Son Şans”, Türk Turizm Araştırmaları Dergisi, 3(3), s.421-435.

Görsel 2. Cihat, B. Kuşevi, https://tr.pinterest.com/pin/548102217126228942/ (27.06.2020)

Görsel 3. Cihat, B. Kuşevi, https://tr.pinterest.com/pin/548102217135843944/ (27.06.2020)

Görsel 4. Ciha, B. Kuşevi, https://dergipark.org.tr/tr/download/article-file/192435 (27.06.2020)

Görsel 5. Cihat, B. Kuşevi, https://dergipark.org.tr/tr/download/article-file/192435 (22.07.2020)

Görsel 6. Deniz, O. E. Kuşevi, https://www.galerisoyut.com.tr/deniz-onur-erman2017/\#eser/abaef12f29fd3714d0084ec6d029f44e/12888 (27.06.2020).

Görsel 7. Deniz, O. E. Kuşevi, https://www.galerisoyut.com.tr/deniz-onur-erman2017/\#eser/abaef12f29fd3714d0084ec6d029f44e/12887 (27.06.2020).

Görsel 8. Mezahir, E. A. Kuşevleri, (Gülşen Kahraman Kişisel Arşiv).

Görsel 9. Jim, S. Yumurta Görünümlü Kuşevi Çalışması, https://jschatz.com/collections/j-schatzearth-birds/products/egg-bird-house-in-bronze (26.06.2020)

Görsel 10. Jim, S. Yumurta Görünümlü Kuşevi Çalışması, https://www.craftcouncil.org/magazine/article/j-schatz\#\&gid=1\&pid=2 (26.06.2020).

Görsel 11. Douglas, F. Atölye Ortamında Çalışması, https://www.facebook.com/Douglas-FeyPotter\%20214672611877937/photos/a.214672858544579/218828021462396 (26.06.2020).

Görsel 12. Douglas, F. Kedi Çıkışlı Kuşevi, http://www.douglasfeypottery.com/galleries-ofcritters/cats-cows-.html (26.06.2020).

Görsel 13. Douglas, F. Balık Çıkışlı Kuşevi, http://www.douglasfeypottery.com/galleries-ofcritters/fish-frogs-lizards.html (26.06.2020) 
Görsel 14. Stanley, C. B. Seramik Kuşevi, https://www.thehomelifemag.com/wp-image/outdoor/stanbitters-ceramic-birdhouses.jpg (14.06.2020).

Görsel 15. Stanley, C. B. Seramik Kuşevi, http://www.stanbitters.com/teracotta-bird-house/ (27.06.2020).

Görsel 16. Stanley C. B. Seramik Kuşevi, http://www.stanbitters.com/6-colors-bird-house/ (27.06.2020).

Görsel 17. Joop, V. U. Seramik Kuşevleri, https://www.joopvanulden.nl/gallery?id=200;3 (28.06.2020).

Görsel 18. Michael, M. Seramik Kuşevi, http://2.bp.blogspot.com/_lofizJ7zoB8/Sh7OUGwJ2zI/AAAAAAAAF0Q/K4ihQaxmydY/s1600$\mathrm{h} /$ ceramicPotteryBird\%20House.jpg (27.06.2020).

Görsel 19-41. Gülşen Kahraman, Kişisel Arşiv, 2018-2019. 